\title{
Nitrosation of Hemoglobin from Animal Blood as a Colorant of Meat Products
}

\author{
Ryoichi Sakata, Guisong Lee and Yukiharu Nagata \\ School of Veterinary Medicine, Azabu University, \\ Sagamihara-shi 229
}

(Received June 17, 1992)

\begin{abstract}
The purpose was examination of the following : 1) reaction conditions for the preparation of stable nitrosohemoglobin ( $\mathrm{NOHb}$ ) obtained by the nitrosation of hemoglobin $(\mathrm{Hb})$ from animal blood and 2) the possibility of augmenting meat product color by the addition of $\mathrm{NOHb}$ which can be prepared easily in the native state and followed by cooking. More than $80 \%$ of total $\mathrm{Hb}$ in a mixture of $100 \mathrm{mM} \mathrm{NaNO} \mathrm{N}_{2}-100 \mathrm{mM}$ sodium ascorbate $(\mathrm{NaAsA})$ was nitrosated, and $\mathrm{NO}_{2}^{-}$was found present at $3,600 \mathrm{ppm}$ on the 10 th day of storage at $2^{\circ} \mathrm{C}$. The nitrosation of $\mathrm{Hb}$ in the mixture $\left(25 \mathrm{mM} \mathrm{NaNO}_{2}\right.$ $25 \mathrm{mM} \mathrm{NaAsA}, \mathrm{pH} 4.5)$ proceeded rapidly, and the color forming ratio was $85 \%$ even at 14 days of storage. Added nitrite could not be detected after 3 days of storage. $0.5 \%$ and $1 \%$ of the $\mathrm{NOHb}$ reaction mixture were added to porcine muscle with $2 \% \mathrm{NaCl}, 200 \mathrm{ppm}$ $\mathrm{NaNO}_{2}$ and $0.1 \% \mathrm{NaAsA}$. The sausage was prepared for assessment of color formation. The following results were obtained: Nitroso heme pigments were formed to a greater extent than those of the control (without addition of $\mathrm{NOHb}$ ) meat product; $\mathrm{NOHb}$ in the $\mathrm{Hb}$ reaction mixture had a qualitative effect on meat color formation.
\end{abstract}

Anim. Sci. Technol. (Jpn.) 63 (12) : 1247-1252, 1992

Key words : animal blood, hemoglobin, color formation, nitrosohemoglobin.

Most animal blood from slaughterhouses is used for fertilizer and animal feed even though it is a valuable source of protein. There are many problems involved in the use of blood as food material. The red cell fraction, erythrocytes, though high in nutritional value, is difficult to use as a food component compared to that of the plasma fraction, according to reports on the utilization of iron by protease treatment ${ }^{1)}$, fermented seasoning ${ }^{5,9)}$ and decolorized globin ${ }^{16)}$. The use of erythrocytes in food is hindered most due to the dark brownish color it imparts following heat treatment even when present in a minute amount. The reason for this is that $\mathrm{Hb}$ (hemoglobin), the major part of the erythrocytes, is converted to heatdenatured methemoglobin. Attempts have been made to stabilize $\mathrm{Hb}$ so that it will retain its red color as a coloring agent for processed meat products. MARUYAMA ${ }^{7)}$ carried out the nitrosation of $\mathrm{Hb}$ with nitrite and ascorbate, cooked the pigment and solubilized the heme group by the decomposition of globin portion with protease treatment. SHAHIDI and PEGG ${ }^{12-14)}$ conducted the nitrosation of $\mathrm{Hb}$ from animal blood and obtained nitrosohemochrome by heating NOHb (nitroso hemoglobin). Though it was the purpose in these studies to use this pigment as a colorant for meat products, heat-denatured NOHb (nitrosohemochrome) was noted to be unstable and oxidized to a brown color with the passage of time ${ }^{15)}$, ITO $^{2)}$ carried out the electrolytic reduction of heme proteins to obtain meat colorants and augment the red color of meat products through their addition during curing. 
To utilize the red cell fraction from slaughtered animals, this investigation was made of the following using commercial $\mathrm{Hb}$ powder : 1) reaction conditions for preparing stable $\mathrm{NOHb}$ and 2) the possibility of augmenting meat product color by the addition of $\mathrm{NOHb}$ readily obtainable in the native state and then by cooking.

\section{Materials and Methods}

Preparation of $\mathrm{Hb}$ solution: $\mathrm{Hb}$ powder from cattle blood (Harimex Co. Ltd.) was dissolved in $\mathrm{H}_{2} \mathrm{O}$, and glucose at concentrations of $18 \%$ and $40 \%$ respectively. The solution was stored overnight at $2^{\circ} \mathrm{C}$. The mixture was subsequently centrifuged at $9,000 \times \mathrm{G}$ for 10 min at $4^{\circ} \mathrm{C}$ and the supernatant was used as $\mathrm{Hb}$ solution.

Preparation of $H b$ reaction mixture: $\mathrm{Hb}$ reaction mixtures were prepared by mixing the $\mathrm{Hb}$ solution $(50 \mathrm{~g})$ with $\mathrm{NaCl}(2 \%), \mathrm{NaNO}_{2}$ (3.1-100 mM) and sodium ascorbate (NaAsA, the same level as $\mathrm{NaNO}_{2}$ ). The final weight of each mixture was $53 \mathrm{~g}$, and each was analyzed for NOHb formation during storage at 2 or $20^{\circ} \mathrm{C}$.

Preparation of pork sausage after adding the $\mathrm{Hb}$ reaction mixture : 0.5 and $1 \% \mathrm{Hb}$ reaction mixtures after several days of storage were added to porcine muscle ( $M$. longissimus thoracis, relatively lighter color) with $2 \% \mathrm{NaCl}$, $0.02 \% \mathrm{NaNO}_{2}$ and $0.1 \% \mathrm{NaAsA}$. Sausage was prepared for color assessment and comparison was made with a control sample containing all the curing agents but $\mathrm{NOHb}$.

Color foming ratio determination: The color forming ratio (CFR) of each mixture was determined by the method of the authors ${ }^{10,11}$, and expressed as $\% \mathrm{NOHb}$ to total $\mathrm{Hb}$. In the case of sausage to which $\mathrm{NOHb}$ had been added, total and nitroso heme pigments were extracted with $75 \%$ acetone- $0.7 \% \mathrm{HCl}$ and $75 \%$ acetone respectively, in the same manner as for the $\mathrm{Hb}$ reaction mixture. Hunter values were also measured by a color difference meter (Nip- pon Denshoku Kogyo Co. Ltd., Model ND-1001 DP).

Determination of residual nitrite: The $\mathrm{NOHb}$ extract obtained with $75 \%$ acetone was used to determine nitrite content according to the method of Mirna and SCHÜTz ${ }^{8)}$.

\section{Results and Discussion}

Effects of $\mathrm{NaNO}_{2}$ and $\mathrm{NaAsA}$ concentrations on $\mathrm{Hb}$ nitrosation and residual nitrite: The concentrations of $\mathrm{NaNO}_{2}$ and $\mathrm{NaAsA}$ for this study were decided on based on the reports of LeE and CASSENS ${ }^{6)}$ and ShahIDI and PEGG ${ }^{13-15)}$. More than $80 \%$ of the total $\mathrm{Hb}$ of a mixture (pH 7.3-7.6) of $100 \mathrm{mM} \mathrm{NaNO}_{2}-100 \mathrm{mM} \mathrm{NaAsA}$ was nitrosated on the 1st day of storage (Fig. 1). CFR of the reaction mixture showed no change even after 1 month of storage at $2^{\circ} \mathrm{C}$ or 10 days at $20^{\circ} \mathrm{C}$ in the dark. Though $\mathrm{NOHb}$ in the mixture remained stable, $\mathrm{NO}_{2}^{-}$content was $3,600 \mathrm{ppm}$ at 10 days of storage at $2^{\circ} \mathrm{C}$, this being $76 \%$ of the original amount. $\mathrm{NOHb}$ content in the reaction mixture with $25 \mathrm{mM}$

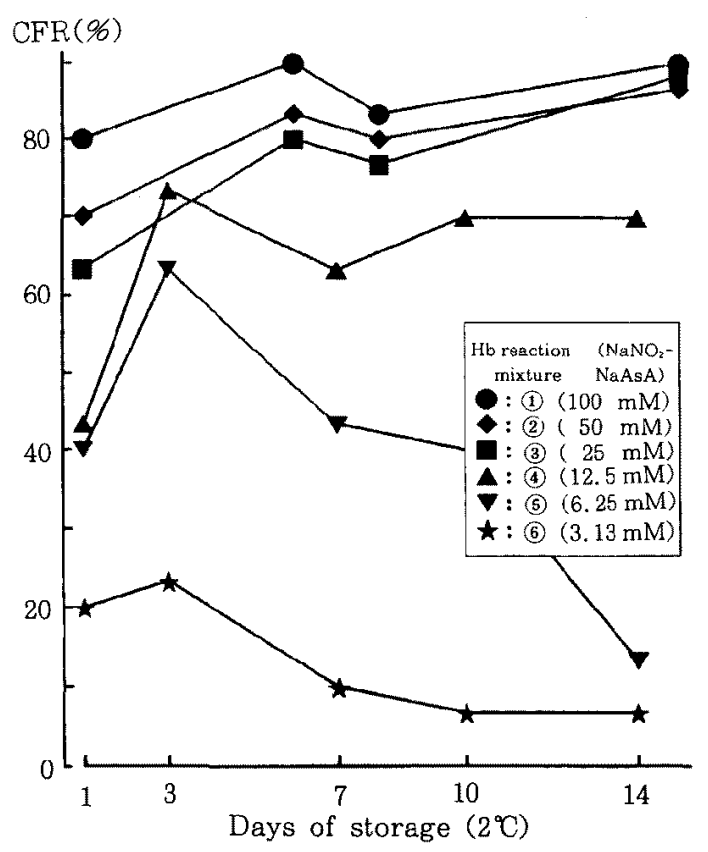

Fig. 1. CFR of the $\mathrm{Hb}$ reaction mixture. 
Nitrosation of Animal Blood Hemoglobin

$\mathrm{NaNO}_{2}-25 \mathrm{mM} \mathrm{NaAsA}$ was $80 \%$ in $\mathrm{CFR}$ at 8 days of storage, and its formation occurred in essentially the same manner at $100 \mathrm{mM}$.

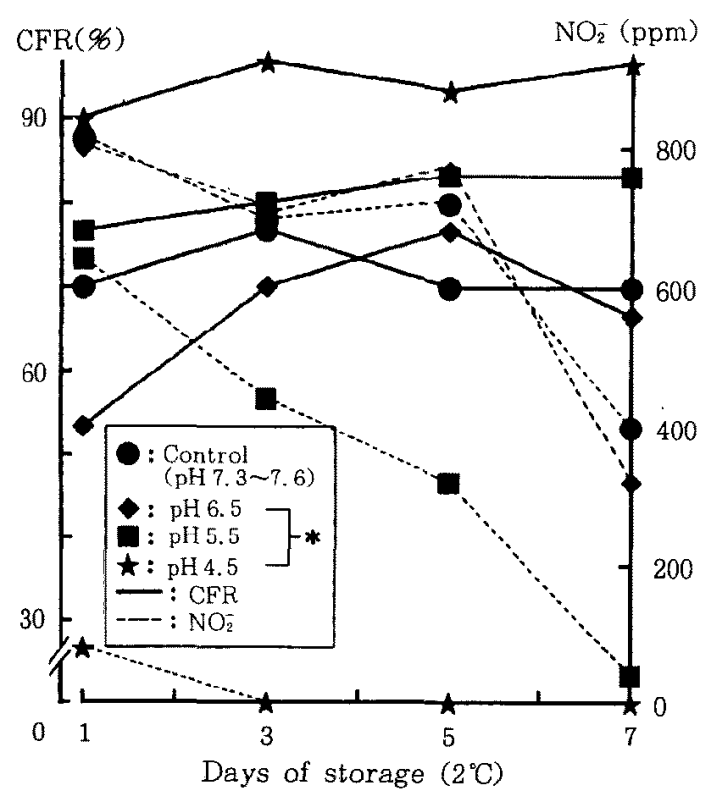

Fig. 2. Effects of $\mathrm{pH}$ on CFR and residual nitrite content of the $\mathrm{Hb}$ reaction mixture (25 $\mathrm{mM} \mathrm{NaNO}_{2}-25 \mathrm{mM} \mathrm{NaAsA}$ ).

* Adjusted with lactic acid.

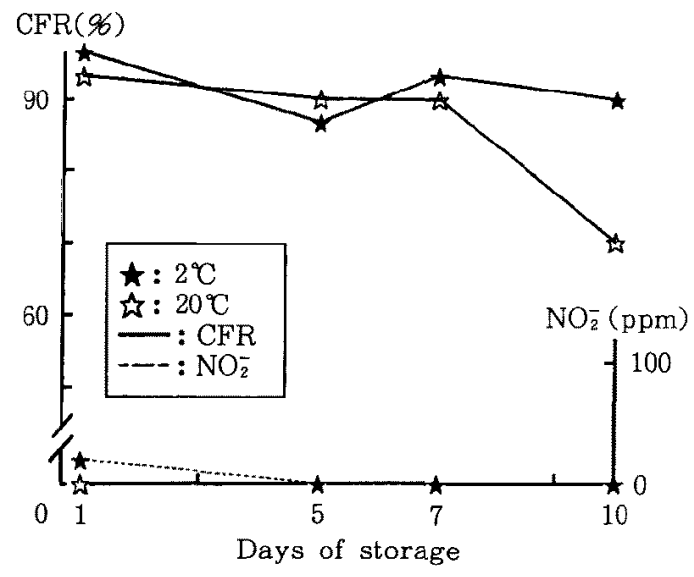

Fig. 3. Effects of temperature on CFR and residual nitrite content of the $\mathrm{Hb}$ reaction mixture $\left(25 \mathrm{mM} \mathrm{NaNO}_{2}-25 \mathrm{mM} \mathrm{NaAsA}, \mathrm{pH}\right.$ $4.5)$.
This value is in agreement with general type CFR of cooked cured meat products ${ }^{10,11\}}$, Residual nitrite decreased in the $25 \mathrm{mM} \mathrm{NaNO}_{2}-$ $\mathrm{NaAsA}$ reaction mixture with storage, and $\mathrm{NO}_{2}^{-}$ was $480 \mathrm{ppm}$ after 8 th day of storage (data not shown). No residual nitrite was detected in the reaction mixture of $12.5 \mathrm{mM}$ and was below the level of $\mathrm{NaNO}_{2}-\mathrm{NaAsA}$ after reaction for 3 days. However, CFR of these mixtures did not exceed $80 \%$, indicating the nitrosation of $\mathrm{Hb}$ not to easily proceed with decrease in nitrite and ascorbate content. The

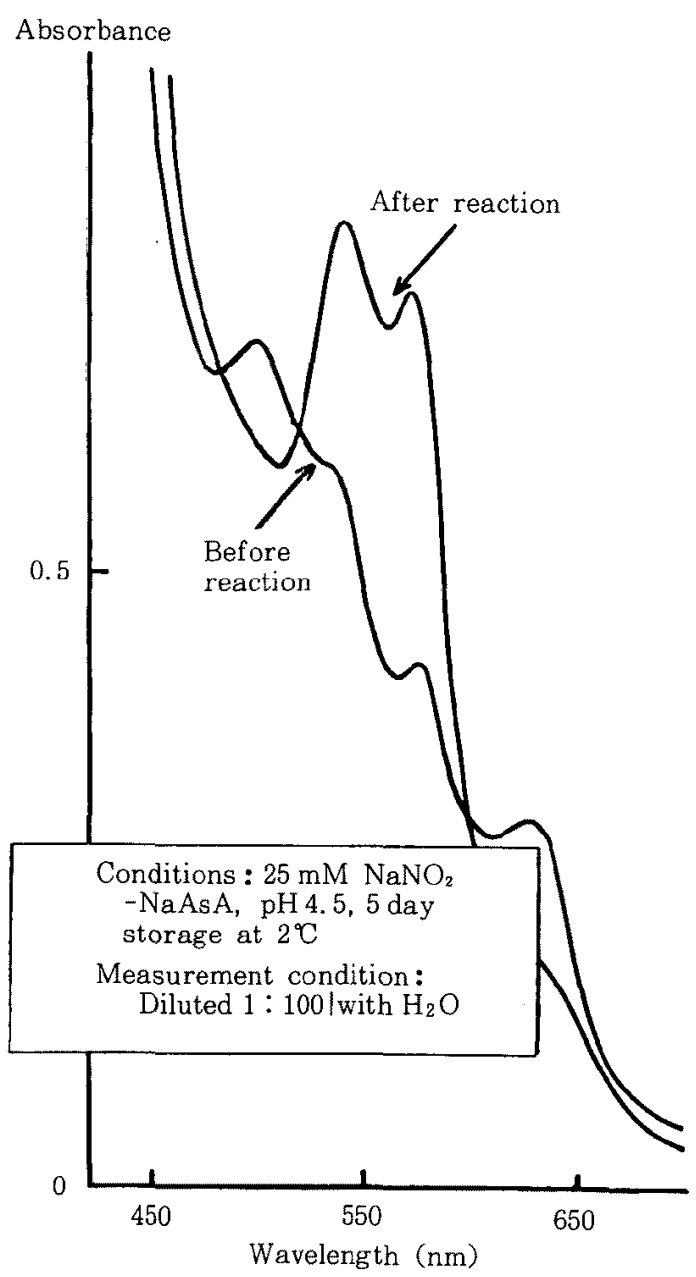

Fig. 4. Absorption spectra of the $\mathrm{Hb}$ reaction mixture. 
following experiments were thus conducted to determine the conditions most suitable for using a $25 \mathrm{mM} \mathrm{NaNO}{ }_{2}-25 \mathrm{mM} \mathrm{NaAsA}$ reaction mixture.

Effects of $p H$ on $C F R$ and residual nitrite content of the reaction mixture: Fig. 2 shows $\mathrm{CFR}$ and $\mathrm{NO}_{2}^{-}$of the reaction mixture with $25 \mathrm{mM} \mathrm{NaNO}_{2}-25 \mathrm{mM} \mathrm{NaAsA}$ at varied $\mathrm{pH}$ adjusted with lactic acid. Compared with the control sample with unadjusted $\mathrm{pH}, \mathrm{CFR}$ of the pH 4.5 mixture exceeded $90 \%$ by the 3 rd day of storage at $2^{\circ} \mathrm{C}$. More than $85 \%$ in CFR was maintained even for 14 days. Added nitrite could not be detected after 3 days of storage. CFR of the reaction mixture at $\mathrm{pH} 4.5,20^{\circ} \mathrm{C}$ had decreased on the 10th day of storage, and no residual nitrite could be detected during storage (Fig. 3).

The presence of an intermediate (nitrosoascorbic acid) as reported by IzUmi et al. ${ }^{3,4)}$ may possibly be the reason for the absence of free nitrite. They consider that such an intermediate may be formed by the interaction of nitrite and ascorbic acid with concomitant increase in the rate constant of this reaction with decrease in $\mathrm{pH}$ in model meat-curing brine. This appeared to be the case in the present study. Nitrite would thus appear to easily react with ascorbate with decrease in $\mathrm{pH}$, with consequent acceleration of the nitrosation of $\mathrm{Hb}$.

The absorption spectra of $\mathrm{NOHb}$ formed with the $25 \mathrm{mM} \mathrm{NaNO}{ }_{2}-25 \mathrm{mM} \mathrm{NaAsA}$ reaction mixture are shown in Fig. 4. Before the reaction, spectral scanning indicated a pattern for the formation of oxy-and met-hemoglobin due to the presence of both pigments. At 5 days, $2^{\circ} \mathrm{C}$ and $\mathrm{pH} 4.5$, the typical spectral pattern of $\mathrm{NOHb}$ was observed. Most $\mathrm{Hb}$ was confirmed to be nitrosated under the experimental conditions used.

Effects of $\mathrm{Hb}$ reaction mixture on experimental sausages: The $\mathrm{Hb}$ reaction mixture (CFR : $86.8 \%$ ) was added to minced porcine muscle, and sausage was prepared (Table 1). Following 0.5 and $1 \%$ additions of the reaction

Table 1. Effect of addition of $\mathrm{Hb}$ reaction mixture to experimental sausages (I)

\begin{tabular}{|c|c|c|c|c|c|c|c|c|}
\hline & \multirow{2}{*}{\multicolumn{2}{|c|}{ Sample ${ }^{1}$}} & \multirow{2}{*}{$\mathrm{pH}$} & \multicolumn{3}{|c|}{ Hunter value } & \multirow[b]{2}{*}{$\begin{array}{l}\mathrm{CFR} \\
(\%)\end{array}$} & \multirow[b]{2}{*}{$\begin{array}{l}\text { Residual } \\
\mathrm{NO}_{\overline{2}} \text { (ppm) }\end{array}$} \\
\hline & & & & $\mathrm{L}$ & $\mathrm{a}$ & $b$ & & \\
\hline (1) Control & $\left\{\begin{array}{l}\mathrm{NaCl} \\
\mathrm{NaNO} \\
\mathrm{NaAsA}\end{array}\right.$ & $\begin{array}{l}2(\%) \\
0.02 \\
0.1\end{array}$ & 5.87 & 60.2 & 14.5 & 8.2 & 86.8 & 15.3 \\
\hline (2) (1) $+\mathrm{Hb}$ & $\begin{array}{l}\text { reaction } \\
\text { mixture }\end{array}$ & 0.596 & 5.88 & 56.5 & 15.2 & 8.4 & 89.0 & 16.0 \\
\hline (3) (1) $+\mathrm{Hb}$ & $\begin{array}{l}\text { reaction } \\
\text { mixture }\end{array}$ & $1.0 \%$ & 5.84 & 54.0 & 15.5 & 8.5 & 86.2 & 17.1 \\
\hline
\end{tabular}

${ }^{1}$ Added to porcine muscle (M. longissimus thoracis) $\rightarrow$ Stuffed into polyvinylidene chloride casing $(50 \mathrm{~mm}) \rightarrow$ Cooked at $75^{\circ} \mathrm{C}$ for $60 \mathrm{~min}$.

${ }^{2}$ Contained $10.96 \% \mathrm{Hb}, 2 \% \mathrm{NaCl}, 25 \mathrm{mM} \mathrm{NaNO} 225 \mathrm{mM} \mathrm{NaAsA}$ and $40 \%$ glucose (pH 4.8), and kept for 10 days at $2^{\circ} \mathrm{C}$ after preparation $(\mathrm{CFR}=86.8 \%)$.

Table 2. Effect of addition of $\mathrm{Hb}$ reaction mixture to experimental sausages (II)

\begin{tabular}{|c|c|c|c|c|c|c|}
\hline \multirow{2}{*}{ Sample } & \multirow{2}{*}{$\begin{array}{l}\text { Addition } \\
\text { level } \\
\text { of } \mathrm{Hb}\end{array}$} & \multicolumn{2}{|c|}{ Nitroso heme pigment $(\mathrm{NOHP})^{1}$} & \multicolumn{2}{|c|}{ Increase in $\mathrm{NOHb}$} & \multirow{2}{*}{$\begin{array}{l}\text { Increase rate } \\
\text { of NOHP } \\
(\mathrm{B}-\mathrm{A}) / \mathrm{A} \times 100\end{array}$} \\
\hline & & $-\mathrm{Hb}(\mathrm{A})$ & $+\mathrm{Hb}(\mathrm{B})$ & Observed (B-A) & Calculated ${ }^{2}$ & \\
\hline \multirow{3}{*}{$\begin{array}{l}\text { Pork } \\
\text { sausage }\end{array}$} & (\%) & $(8)$ & $(\%)$ & $(96)$ & (\%) & (\%) \\
\hline & 0.5 & 0.129 & 0.185 & 0.056 & 0.049 & 43.4 \\
\hline & 1.0 & 0.129 & 0.225 & 0.096 & 0.097 & 74.4 \\
\hline
\end{tabular}

${ }^{1}$ Expressed as the level of NOHb. ${ }^{2}$ Level of NOHb from $\mathrm{Hb}$ reaction mixture added. 
mixture, Hunter a-values as well as CFR increased. Redness was also greater than that of the control. In Table 2, the formation of nitroso heme pigments can be seen to be greater than that of the control meat product (without $\mathrm{NOHb})$. The nitroso heme pigments increased to 43.4 and $74.4 \%$ respectively after adding $\mathrm{Hb}$ at 0.5 and $1 \%$. NOHb in the reaction mixture thus augments the color of cooked cured meat products. Although similar results were obtained by SHAHIDI and PEGG ${ }^{12-14}$, their preparation was denatured $\mathrm{NOHb}$ by preheating, and it has been pointed out that such a preparation is unstable due to oxidation with time $^{15)}$. Residual nitrite in the sausage did not increase significantly by the addition of the reaction mixture, which is in good agreement with Izumi and CAssens ${ }^{3}$. They injected brine containing $\mathrm{NaNO}_{2}$ and ascorbic acid at pH 4.0 or 4.5 and as a result could obtain bacon with an extremely small amount of residual nitrite.

The direct preparation of $\mathrm{NOHb}$ from $\mathrm{Hb}$ of animal blood should be conducted so that $\mathrm{NOHb}$ can be used as a colorant in meat processing and reduce nitrite content in processed meat products.

\section{Acknowledgement}

The present study was supported in part by a research grant from the Ito Foundation, Tokyo. The authors thank Mitsubishi Kasei Co. Ltd. for providing the cattle hemoglobin powder.

\section{References}

1) BANDo, T., Utilization of "Heme-Fe" preparation as iron-fortified food material. New Food Industry, 31:6-16. 1989.

2) ITo, T., S. Yoshida, H. Kamisoyama and H. TanaKa, Electrolytic reduction of heme proteins: Attempt to prepare stable natural colorant for sausage. J. Food Sci., 55 : 1689-1695. 1990.

3) IzUmi, K. and R.G. CAssens, Interaction of nitrite, ascorbic acid and $\mathrm{pH}$ in a model meat-curing brine. Fleischwirtsch., $69: 64^{-}$ 65. 1989.
4) Izumi, K., R.G. Cassens and M.L., GREASER, Reaction of nitrite with ascorbic acid and its significant role in nitritecured food. Meat Sci, 26 : 141-153. 1989.

5) Kodama, M., T. Ogata and T. Nakamura, Application of blood protein hydrolyzates to seasoning. Nippon Shokuhin Kogyo Gakkaishi, $30: 384-388.1984$.

6) LeE, S.H. and R.G. CASSENS, Nitrite binding sites on myoglobin. J.Food Sci., 41 : 969-970. 1976.

7) Maruyama, T., Kokkai Patent Gazette (Japan), 48-28673, 511-514. 1973.

8) Mirna, A. and G. SchüTz, Verfahren zur glcichzeitigen Bestimmung des Pökelfarbstoffes sowie von Nitrit und Nitrat in Fleischerzeugnissen. Fleischwirtsch., 52 : 1337-1338. 1972

9) Nakamura, T., Y. Yano and T. Hada, Studies on fermented seasoning production from meat and meat by-products. Jpn. J. Zootech. Sci., 56 : 851-858. 1985.

10) Sakata, R., M. Onso and Y. Nagata, Effect of porcine muscle conditions on the color of cooked cured meat products. Agric. Biol. Chem., 15 : 2077-2088. 1981.

11) Sakata, R. and Y. Nagata, Farbentwicklungsmechanismus bei gekochtem gepökeltem Schweinefleisch beruhend auf einem endogenen Faktor. Fleischwirtsch., 71: 1209-1212. 1991.

12) Shahidi, F. and R.B. PegG, Synthesis of cooked-meat pigment, dinitrosyl ferrohemochrome, and its colour characteristics. Proc. 34th Inter. Cong. Meat Sci. and Technol., Brisbane, 357-359. 1988.

13) Shahid, F. and R.B. PegG, Colour characteristics of cooked cured-meat pigment and its application to meat. Food Chem., $38: 61-68.1990$

14) Shahidi, F. and R.B. PegG, Novel synthesis of cooked cured-meat pigment. J. Food Sci., 56: 1205-1208. 1991.

15) SMith, J.S. and D.L. Jr. Burge, Protoporphyrin-IX as a substitute for nitrite in cured-mest color production. J. Food Sci., 52 : 1728-1729. 1987.

16) Tybor, P.T., C.W. Dill and W.A. LANDMANN, Functional properties of proteins isolated from bovine blood by a continuous pilot process. J. Food Sci., 40 : 155-159. 1975. 


\title{
屠畜血液へモグロビンのニトロソ化と肉製品への利用
}

\author{
坂田亮一・李 貴松・永田致治
}

麻布大学獣医学部, 相模原市 229

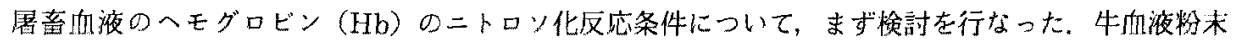
より調製した $\mathrm{Hb}$ 溶液に $\mathrm{NaNO}_{2}$ とアスコルビン酸ナトリゥム（NaAsA）をそれぞれ $100 \mathrm{mM}$ 添加 した場合, 反応 1 日目において全 Hbの $80 \%$ 以上がニトロソ化した。この反纫液中のニトロソへモグ

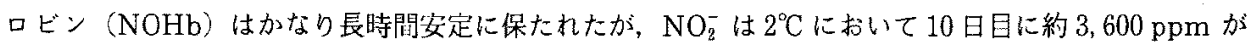
残存した。 反応条件について検討し得られた $25 \mathrm{mM} \mathrm{NaNO}_{2}-25 \mathrm{mM} \mathrm{NaAsA}, \mathrm{pH} 4.5$ の $\mathrm{Hb}$ 反応 液では，Hb の二トロソ化が速やかに進行し，発色率は $2^{\circ} \mathrm{C}$ で眝藏 14 日目においても $85 \%$ 以上を保持 し，一方， $20^{\circ} \mathrm{C}$ では 10 日目に扔いて明らかな減少が観察された。眝蔵中の $\mathrm{Hb}$ 反応液に $\mathrm{NaNO}_{2}$ は 険出されなかった，次に，この条件で調製した $\mathrm{Hb}$ 反应液を。原料肉に対し $0.02 \% \mathrm{NaNO}_{2}-0.1 \%$ $\mathrm{NaAsA}$ とともに 0.5 扰よび $1 \%$ 添加し試作したンーセージの発色状態を調べた．その結果， Hb 反応 液の添加によって発色は増強され, 定量したりーセージ中のニトロソへム色素の増強割合から, 添加し た Hb 反応液中の NOHb は，ほぼ定量的にンーセージの発色に寄与していることが確琶された。
\end{abstract}

日畜会報, $63(12) ： 1247-1252,1992$ 